\title{
Preliminary Study of a Method for Obtaining Brown Coal and Biochar Based Granular Compound Fertilizer
}

\author{
Marzena Mikos-Szymańska ${ }^{1}$ (D) Sebastian Schab ${ }^{1} \cdot$ Piotr Rusek $^{1} \cdot$ Krzysztof Borowik $^{1} \cdot$ Paulina Bogusz $^{1}$. \\ Marta Wyzińska²
}

Received: 31 October 2018 / Accepted: 20 March 2019 / Published online: 30 March 2019

(c) The Author(s) 2019

\begin{abstract}
A purpose of the research was to develop a method for the preparation of novel organo-mineral fertilizers with the use of brown coal and biochars as organic additives. Brown coal was blended simultaneously together with inorganic materials used for the process of urea superphosphate production in a laboratory scale using a pan granulator and in larger scale using a rapid mixer granulator. Biochars were used for the coating purposes of the urea superphosphate granules on a laboratory scale using a pan granulator. Moreover, the aim was to measure and evaluate the physico-chemical properties of organic materials and the obtained organo-mineral fertilizer products and to study the effects of these products on the selected yield components of spring wheat such as grain yield per plant, spike number per plant, and plant height, in pot trials. Results showed that brown coal and biochars can be used as raw materials for production of fertilizer products. Brown coal contained about $50 \%$ of total humic acids while biochar contained nearly $6 \%$ of total humic-like substances. Brown coal based compound fertilizer granules produced in the large scale were characterized by particle hardness from 15.80 to $23.3 \mathrm{~N}$ while those produced in the laboratory scale were classified as "soft" (particle hardness below 2.3 N). The application of brown coal based fertilizers and two studied biochar coated fertilizers had a positive impact on the grain yield per plant of spring wheat.
\end{abstract}

Keywords Brown coal $\cdot$ Biochar $\cdot$ Granulation $\cdot$ Humic acids $\cdot$ Fertilizer quality

\section{Statement of Novelty}

The research was undertaken to develop a production method of a novel organo-mineral fertilizer based on bio-feedstocks. Brown coal and biochars were used as fertilizer components to improve the fertilizer use efficiency and soil properties in order to stimulate the plant growth. The method for the incorporation of brown coal into the urea superphosphate formulation was done for the first time. Three different biochars were used for coating purposes of urea superphosphate granules. It was found that water as a binder together with biochar can act well as coating materials but additional study

Marzena Mikos-Szymańska

marzena.mikos-szymanska@ins.pulawy.pl

1 Fertilizer Department, New Chemical Syntheses Institute, Al. Tysiąclecia Państwa Polskiego 13A, 24-110 Puławy, Poland

2 Institute of Soil Science and Plant Cultivation - State Research Institute, Ul. Czartoryskich 8, 24-100 Puławy, Poland is necessary to improve abrasion resistance of the coated fertilizer granules. The brown coal and biochar based fertilizers had a positive influence on a spring wheat yield.

\section{Introduction}

Nowadays, there is clear evidence of a decline in the organic carbon contents in many soils as a consequence of the intensification of agriculture over past years [1,2]. Organic carbon is a major component of soil organic matter that plays an important role in the formation of stable aggregates of the soil structure [2]. Moreover, soil organic matter acts as a storehouse for nutrients, is a source of soil fertility, improves infiltration rates, increases the storage capacity for water, serves as a buffer against changes in soil reaction $(\mathrm{pH})$, and acts as an energy source for soil microorganisms [2]. Thus, improving nutrient use efficiency (NUE) and reversing the loss of soil organic matter are major global challenges. One possibility to improve the soil properties can be to use soil improvers, organic and organo-mineral fertilizers. 
Brown coal that is characterized by very low heating value can be used as a component of organo-mineral fertilizers. It contains organic matter in a complex, porous, threedimensional network, which varies depending on deposit location. Humic acids are very important components of brown coal and can account $10-80 \%$ of its organic matter [3]. They contain many functional chemical groups that help to physically modify and improve the chemical properties of the soil and biologically stimulate plant growth [4]. Thus, humic acid products mainly as plant growth enhancers and as ingredients of fertilizer products are widely distributed throughout the world. Brown coal is an alternative material with properties that make it appealing for use as a $\mathrm{N}$ fertilizer carrier. The study found [5] that its incorporation into soil slightly reduced ammonium availability in one soil. Brown coal-urea blended fertilizers show potential for more efficient use of $\mathrm{N}$ in the long term and has environmental benefits in retaining more $\mathrm{N}$ in the soil [6].

Biochar is the residue of pyrolysis and is often used to pre-dried biomass feedstock or is sold as charcoal briquettes. A novel approach is to explore the value of this by-product for coating purposes of the mineral fertilizers. According to Lehmann [7] two aspects of biochar make it valuable for the purpose of adding this material to soil: (i) high stability against decay and (ii) its superior ability to retain nutrients as compared to other forms of soil organic matter. Thus, three environmental benefits arise from these properties: (i) mitigation of climate change, (ii) improvement of soils, and (iii) reduction of environmental pollution [7].

Biochar created from waste biomass (e.i., waste wood or plant material after extraction) by pyrolysis technique $[8,9]$ can contain certain amounts of extractable humic-like and fulvic-like substances [10]. A number of studies [5, 11, 12] show that biochars can reduce nitrate and ammonium leaching from applied nitrogen fertilizers, but the effectiveness depends on the chemical characteristics of biochars and their rate of application. In agriculture, over-fertilization results in a decrease of fertilizer use efficiency and leads to environmental and ecological problems. The use of controlled release or slow release fertilizers may increase nutrient use efficiency. Controlled release fertilizers (CRFs) could release nutrients gradually, which try to coincide with the nutrient demand during crop growth. Slow release fertilizers (SRFs) are characterized by the release of the nutrients at a slower rate than is usual but the rate, pattern, and duration of release are not well controlled [13]. Previous studies [14, 15] indicated that biochar can be used as the component of coating materials for fertilizers and its addition increases the degradability of polymer film, which is attributed to the fact that biochar could adsorb soil microorganisms.

The present work attempts to develop a method for the preparation of novel organo-mineral fertilizers with the use of brown coal and biochars as organic additives. Brown coal together with inorganic raw materials, which are used in urea superphosphate production, were granulated using two granulation methods: pan granulation and high shear granulation. Moreover, the coating process of urea superphosphate granules using three types of biochars was studied. The physico-chemical properties of the obtained organo-mineral fertilizers were investigated. The effect of brown coal based fertilizers and biochar coated fertilizers on spring wheat in pot experiments was evaluated.

\section{Materials and Methods}

\section{Raw Materials}

Phosphorite (Djebel Onk, Algeria) bought from the Chemical Plant "Siarkopol” TARNOBRZEG Sp. z o.o. (Poland) was used. Table 1 shows the chemical composition of phosphorite. The phosphate flour was also characterized according to its particle size distribution (Table 2).

Technical sulfuric acid (conc. 95\%), gaseous ammonia $\left(\mathrm{NH}_{3}-\min 99.8 \mathrm{wt} \%\right)$, granular urea $(\mathrm{N}-\min 46 \mathrm{wt} \%$, biurea-max $1.2 \mathrm{wt} \%$, moisture-max $0.3 \mathrm{wt} \%$ ) were from

Table 1 Chemical composition of phosphorite

\begin{tabular}{|c|c|c|}
\hline Paramater & Unit & Result \\
\hline $\mathrm{P}_{2} \mathrm{O}_{5}$ & $\mathrm{wt} \%$ & 30.01 \\
\hline $\mathrm{CaO}$ & $\mathrm{wt} \%$ & 49.80 \\
\hline $\mathrm{SO}_{4}^{2-}$ & $\mathrm{g} \mathrm{kg}^{-1}$ & 3.65 \\
\hline $\mathrm{Mg}$ & $\mathrm{wt} \%$ & 0.705 \\
\hline $\mathrm{Na}$ & $\mathrm{wt} \%$ & 0.622 \\
\hline $\mathrm{K}$ & $\mathrm{wt} \%$ & 0.110 \\
\hline $\mathrm{SiO}_{2}$ & $\mathrm{wt} \%$ & 2.92 \\
\hline $\mathrm{Fe}_{2} \mathrm{O}_{3}$ & $\mathrm{wt} \%$ & 0.470 \\
\hline $\mathrm{Al}_{2} \mathrm{O}_{3}$ & $\mathrm{wt} \%$ & 0.251 \\
\hline $\mathrm{Cr}$ & $\mathrm{mg} \mathrm{kg}^{-1}$ & 211 \\
\hline $\mathrm{Cd}$ & $\mathrm{mg} \mathrm{kg}^{-1}$ & 15.1 \\
\hline $\mathrm{Ni}$ & $\mathrm{mg} \mathrm{kg}^{-1}$ & 15.7 \\
\hline $\mathrm{Sr}$ & $\mathrm{mg} \mathrm{kg}^{-1}$ & 0.256 \\
\hline $\mathrm{Ti}$ & $\mathrm{mg} \mathrm{kg}^{-1}$ & 161.0 \\
\hline $\mathrm{F}^{-}$ & $\mathrm{mg} \mathrm{kg}^{-1}$ & 197.0 \\
\hline $\mathrm{Cl}^{-}$ & $\mathrm{g} \mathrm{kg}^{-1}$ & 0.161 \\
\hline $\mathrm{HCl}$-insoluble fraction & $\mathrm{wt} \%$ & 1.53 \\
\hline $\mathrm{Hg}$ & $\mathrm{mg} \mathrm{kg}^{-1}$ & 0.021 \\
\hline As & $\mathrm{mg} \mathrm{kg}^{-1}$ & 0.998 \\
\hline $\mathrm{Pb}$ & $\mathrm{mg} \mathrm{kg}^{-1}$ & 4.37 \\
\hline \multicolumn{3}{|l|}{ Loss on ignition (LOI) } \\
\hline $105^{\circ} \mathrm{C}$ & $\mathrm{wt} \%$ & 1.19 \\
\hline $400{ }^{\circ} \mathrm{C}$ & $\mathrm{wt} \%$ & 3.31 \\
\hline $1000^{\circ} \mathrm{C}$ & $\mathrm{wt} \%$ & 9.97 \\
\hline $\mathrm{pH}$ & - & 8.42 \\
\hline
\end{tabular}


Table 2 Particle size distribution of phosphorite flour (sieve analysis)

\begin{tabular}{lr}
\hline Sieve size $(\mathrm{mm})$ & Result \\
\hline 0.2 & 7.26 \\
0.1 & 18.61 \\
0.063 & 9.55 \\
Bottom & 59.17 \\
Dust residue & 5.41 \\
\hline
\end{tabular}

Grupa Azoty Puławy SA (Poland). Caustic magnesite was from MAGNEZYTY "GROCHÓW" S.A. (Inc.) company (Poland). Table 3 shows the physico-chemical properties of magnesite.

Dolomite from dolomite mining company (Górnicze Zakłady Dolomitowe SA), "Siewierz Mine" (Poland) was used. Table 4 shows the chemical composition of dolomite.

Run-of-mine brown coal (BC) from Brown Coal Mine "Sieniawa" (Poland) was used. The coal had a moisture content of $47.7 \%$ (wet basis) and was milled to $<2 \mathrm{~mm}$ particle size. Biochars produced by pyrolysis technique from different feedstocks and under different production conditions were used. Biochar 1 from the Pyreg (Germany) plant was produced from a medicinal plant material after extraction, biochar 2 from the University of Limerick (Ireland) plant was produced from energy-crop willow, and biochar 3 from the Fluid SA (Poland) plant was produced from wood chips.

Urea superphosphate (USP) fertilizer was produced in the pilot plant at the New Chemical Syntheses Institute according to the EP application [16]. Analysis of nutrient contents in urea superphosphate showed that it contained $21 \%$ of $\mathrm{N}$, $10 \%$ of $\mathrm{P}_{2} \mathrm{O}_{5}, 15.9 \%$ of $\mathrm{CaO}$, and $7.9 \%$ of $\mathrm{S}$.

\section{Methods}

\section{Determination of Physico-Chemical Properties of Raw Materials}

A moisture content was determined by a gravimetric method at a temperature of $105{ }^{\circ} \mathrm{C}$ for $4 \mathrm{~h}$. The $\mathrm{pH}$ value was measured in 1:10 sample:water ratio after $0.5 \mathrm{~h}$ shaking. After this, samples were allowed to stand for $30 \mathrm{~min}$ and then $\mathrm{pH}$ value [17] and electrical conductivity (EC) was measured

Table 3 Physico-chemical properties of magnesite (from data specification)

\begin{tabular}{lll}
\hline Parameter & Unit & Result \\
\hline $\mathrm{MgO}$ & wt\% & $70-86$ \\
$\mathrm{CaO}$ & $\mathrm{wt} \%$ & $1.0-1.5$ \\
$\mathrm{Fe}_{2} \mathrm{O}_{3}$ & $\mathrm{wt} \%$ & $1.0-4.0$ \\
$\mathrm{Al}_{2} \mathrm{O}_{3}$ & $\mathrm{wt} \%$ & $0.3-1.0$ \\
$\mathrm{SiO}_{2}$ & $\mathrm{wt} \%$ & Until 10 \\
LOI & wt\% & $2.0-10$ \\
Granularity & $\mathrm{mm}$ & $0-2$ \\
\hline
\end{tabular}

Table 4 Chemical composition of dolomite

\begin{tabular}{lll}
\hline Parameter & Unit & Result \\
\hline $\mathrm{CaO}$ & $w \mathrm{w} \%$ & 31.25 \\
$\mathrm{MgO}$ & $\mathrm{wt} \%$ & 19.11 \\
$\mathrm{Fe}_{2} \mathrm{O}_{3}$ & $\mathrm{wt} \%$ & 2.60 \\
$\mathrm{Al}_{2} \mathrm{O}_{3}$ & $\mathrm{wt} \%$ & 0.12 \\
$\mathrm{HCl}-$ insoluble fraction & $w t \%$ & 0.40 \\
$\mathrm{Cu}$ & $\mathrm{mg} \mathrm{kg}^{-1}$ & 16.3 \\
$\mathrm{Cr}$ & $\mathrm{mg} \mathrm{kg}^{-1}$ & 52.7 \\
$\mathrm{Ni}$ & $\mathrm{mg} \mathrm{kg}^{-1}$ & 32.0 \\
$\mathrm{~Pb}$ & $\mathrm{mg} \mathrm{kg}^{-1}$ & 8.0 \\
$\mathrm{Cd}$ & $\mathrm{mg} \mathrm{kg}^{-1}$ & 0.7 \\
$\mathrm{As}$ & $\mathrm{mg} \mathrm{kg}^{-1}$ & $<8$ \\
$\mathrm{Hg}$ & $\mathrm{mg} \mathrm{kg}^{-1}$ & 0.008 \\
Free oxides $(\mathrm{CaO})$ & $w t \%$ & 0.041 \\
$\mathrm{Molar}$ ratio $\mathrm{CaO} / \mathrm{MgO}$ & - & 1.13 \\
\hline
\end{tabular}

using a multifunction computer meter (Elmetron CX 731, Poland) [18]. Humic acid contents were determined by a volumetric method with titration of extracts according to the international standard [19]. Phosphorus $\left(\mathrm{P}_{2} \mathrm{O}_{5}\right)$ and potassium $\left(\mathrm{K}_{2} \mathrm{O}\right)$ contents were determined in water and acid solutions using a segmented flow analyser (Seal Analytical, Germany). Total contents of these nutrients were determined in ashes of brown coal and biochars after digestion with $\mathrm{HNO}_{3}$ and $\mathrm{HCl}$ (3:1). Metal contents were determined by ICP-OES (Varian 720-ES, Australia) after total digestion $\left(\mathrm{HNO}_{3} / \mathrm{HCl}\right)$ in a microwave (CEM Corporation Mars, USA). The carbon $(\mathrm{C})$, hydrogen $(\mathrm{H})$, and nitrogen $(\mathrm{N})$ contents in samples were determined by combustion analysis using a Perkin Elmer 2400 analyzer. Loss on ignition (LOI) was determined at temperatures of 105,400 , and $1000{ }^{\circ} \mathrm{C}$ in a muffle furnace.

\section{Laboratory Granulation}

Urea was hand-mixed with sulfuric acid and water. The mixture was heated to about $80{ }^{\circ} \mathrm{C}$. Bulk materials such as brown coal and phosphorite flour were mixed in a cube mixer (ERWEKA GmbH, Germany). The urea-sulfuric acid mixture and water were used as binders in a granulation process. For a batch, $1890 \mathrm{~g}$ of wet coal (with moisture of $47.7 \%), 336 \mathrm{~g}$ of phosphorite, $457 \mathrm{~g}$ of urea $(46 \% \mathrm{~N}), 217 \mathrm{~g}$ of technical sulfuric acid (98\%) and $28.2 \mathrm{~g}$ of water were used plus additional water in the amount of $54 \mathrm{~g}$ at the end of the granulation was added. The raw material consumption was as follows: $50 \mathrm{wt} \%$ of brown coal (calculated to dry matter), $16.8 \mathrm{wt} \%$ of phosphorite, $22.9 \mathrm{wt} \%$ of urea, 10.9 wt $\%$ of technical sulfuric acid (calculated as $100 \%$ ) and the water consumption was $4.1 \mathrm{wt} \%$. The granulation was carried out in a pan granulator (ERWEKA GmbH, Germany) 
with a diameter of $400 \mathrm{~mm}$. The binder was sprayed using a hand sprayer (Kwazar Corporation Sp. z o.o., Poland) of the volume of $1 \mathrm{dm}^{3}$ on the bulk materials while the pan granulator was rotating. Granulation occurred in less than $15 \mathrm{~min}$. The granules were air dried for 5 days and dried in a laboratory dryer at $105^{\circ} \mathrm{C}$ for $3 \mathrm{~h}$.

\section{Granulation on a Large Scale}

For granulation on a large scale, a rapid mixer granulator $\left(20 \mathrm{dm}^{3}\right)$ (IdeaPro MDL-04, Poland) was used. This type of the granulator allows intensive mixing and simultaneous granulation of various raw materials. Bulk materials such as brown coal and phosphorite flour were preliminary mixed in the mixer granulator (turbine speed-250 rpm, vessel speed-120 rpm). Urea, sulfuric acid, and water were mixed in a reactor equipped with a heating jacket and then were heated to about $80^{\circ} \mathrm{C}$. The mixture of urea-sulfuric acid was added to bulk materials while the mixer granulator was rotating. In order to increase the $\mathrm{pH}$ value of the final fertilizer products the following additives were used: gaseous ammonia, dolomite, and caustic magnesite.

\section{Laboratory Coating of Mineral Fertilizer Granules}

Coating of urea superphosphate granules using three different biochar materials and water as the binding agent was carried out in the pan granulator (ERWEKA GmbH, Germany). While the granules were rotating in the pan granulator, biochar was manually added and water was sprayed using a hand sprayer (Kwazar Corporation Sp. z o.o., Poland). The samples were called: B1 coated USP (B1-biochar produced from a medicinal plant material after extraction), B2 coated USP (B2-biochar produced from energy-crop willow), B3 coated USP (B3 - biochar produced from wood chips). Biochars constituted $10 \%$ of the total granules mass.

\section{Determination of Physico-Chemical Properties of Fertilizer Products}

Particle hardness of fertilizers $(n=20)$ was determined using ERWEKA TBH 200 apparatus. Results of particle hardness was statistically calculated as a mean value of the test results excluding outliers using Dixon's Q-test. Abrasion resistance of biochar coated USP fertilizer granules were carried out using ERWEKA TA/TAR apparatus (speed $=30 \mathrm{rpm}$; time $=15 \mathrm{~min}$ ). After the above test, granules were handshaken on the sieve and weighted. Results are expressed as a percentage ratio of granules remaining on the sieve with the mesh size of $1.00 \mathrm{~mm}$ to the initial weight of the sample. Sieve analysis was carried out according to the standard method [20] using a vibratory sieve shaker (Retch AS 200, Germany). Particle size distribution of the products was measured by a sieve analysis on vibrating screens $(2.0,2.5$, $3.15,4.0,5.0 \mathrm{~mm})$. The nutrient contents were determined according to methods dedicated for the fertilizer quality analysis [21].

\section{Hygroscopicity}

Hygroscopicity evaluation of brown coal, biochar (B3) and selected fertilizer samples was carried out using desiccators with sulfuric acid solutions of the appropriate concentrations. Sulfuric acid concentrations were as follows: $6.25,5.25,4.91,4.54$, and $3.81 \mathrm{~mol} \mathrm{dm}^{3}$ that provide relative humidity of $44.64,56.77,61.06,65.62$, and $74.06 \%$, respectively. The samples were stored in air atmosphere with different relative humidity for 7 days. The study uses the dependence of relative humidity on the $\mathrm{H}_{2} \mathrm{SO}_{4}$ concentration and assumes that the easiest way to determine hygroscopicity is to measure the mass increases of samples in the atmosphere under different relative humidity. The measurement of hygroscopicity of raw materials and fertilizer samples allows to determine the tendency of the individual sample to absorb water from the environment depending on the air relative humidity.

\section{Pot Trials}

In 2018, a greenhouse experiment was conducted to determine the effects of brown coal based fertilizers and biochar coated fertilisers compared to control, commercial fertilizer, and urea superphosphate (USP) on grain yield per plant, spike number per plant, and plant height of spring wheat $\mathrm{cv}$. Varius. Wheat was grown in pots containing $7 \mathrm{~kg}$ of soil. Fertilizers were applied at a sowing by mixing fertilizer granules with soil. Fertilizer treatments were as follows: $\mathrm{T}_{0}$-control: $2.36 \mathrm{~g}$ MAP (NP 10-55), $3.7 \mathrm{~g} \mathrm{~K}_{2} \mathrm{SO}_{4}$, $10.4 \mathrm{~g}\left(\mathrm{NH}_{4}\right)_{2} \mathrm{SO}_{4} ; \mathrm{T}_{1}-11.48 \mathrm{~g}$ urea superphosphate (NP 21-9), $0.54 \mathrm{~g} \mathrm{KH}_{2} \mathrm{PO}_{4}, 3.35 \mathrm{~g} \mathrm{~K}_{2} \mathrm{SO}_{4} ; \mathrm{T}_{2}-5.88 \mathrm{~g}$ commercial fertilizer NPK(S) 6-12-34-(10), 1.09 g MAP, $9.33 \mathrm{~g}\left(\mathrm{NH}_{4}\right) \mathrm{SO}_{4} ; \mathrm{T}_{3}-25.06 \mathrm{~g}$ brown coal based fertilizer with ammonia $\left(\mathrm{BC}+\mathrm{USP}+\mathrm{NH}_{3}\right), 0.65 \mathrm{~g} \mathrm{KH}_{2} \mathrm{PO}_{4}, 3.29 \mathrm{~g}$ $\mathrm{K}_{2} \mathrm{SO}_{4} ; \mathrm{T}_{4}-29.06 \mathrm{~g}$ brown coal based fertilizer with magnesite (BC+USP + M), $0.49 \mathrm{~g} \mathrm{KH}_{2} \mathrm{PO}_{4}, 3.39 \mathrm{~g} \mathrm{~K}_{2} \mathrm{SO}_{4}$; $\mathrm{T}_{5}-13.50 \mathrm{~g}$ medicinal plant biomass biochar coated urea superphosphate, $0.54 \mathrm{~g} \mathrm{KH}_{2} \mathrm{PO}_{4}, 3.35 \mathrm{~g} \mathrm{~K}_{2} \mathrm{SO}_{4} ; \mathrm{T}_{6}-13.50 \mathrm{~g}$ energy-crop willow biochar coated urea superphosphate, $0.54 \mathrm{~g} \mathrm{KH}_{2} \mathrm{PO}_{4}, 3.35 \mathrm{~g} \mathrm{~K}_{2} \mathrm{SO}_{4}$; and $\mathrm{T}_{7}-13.50 \mathrm{~g}$ wood chips biochar coated urea superphosphate, $0.54 \mathrm{~g} \mathrm{KH}_{2} \mathrm{PO}_{4}, 3.35 \mathrm{~g}$ $\mathrm{K}_{2} \mathrm{SO}_{4}$. Each treatment has received the same dose of NPK (2.4 g N, $1.3 \mathrm{~g} \mathrm{P}_{2} \mathrm{O}_{5}, 2 \mathrm{~g} \mathrm{~K}_{2} \mathrm{O}$ per a pot). Plants were watered to $60 \%$ field capacity. The plant height was measured at a booting stage of wheat development (Feekes scale 10) [22]. 


\section{Results and Discussion}

\section{Raw Materials Characterization}

The physico-chemical properties of brown coal and biochars are presented in Table 5. An understanding of brown coal $\mathrm{pH}$ is important given its likely influence on properties of the final brown coal based fertilizer products. The brown coal sample (Sieniawa mine, Poland) was acidic. The brown coal distillate (coal mine in Eshan county of Yunnan province, China) was also characterized by the acidic $\mathrm{pH}$ value ( $\mathrm{pH} 2-3$ ) [23]. The study conducted by Hoffmann and Huculak-Mączka [24] showed that $\mathrm{pH}$ value of the Polish brown coals was closed to neutral. The brown coal electrical conductivity (EC) was $1.362 \mathrm{dS} \mathrm{m}^{-1}$ and was not very high as compared to water or soil leachate EC values. For example, the EC values of Polish waters under influence of natural salinity usually did not exceed $15 \mathrm{dS} \mathrm{m}^{-1}$ [25]. Moreover, research conducted in Poland showed that the EC of soil saturation extract values from soda industrial area varied between 0.9-15.4 and 1.0-87.2 $\mathrm{dS} \mathrm{m}^{-1}$ for surface and subsurface layer, respectively [26]. The moisture content of brown coals is the important parameter for some applications e.g. for their use as fertilizer components. The moisture of wet brown coal was nearly $50 \%$ and was similar to the moisture of brown coal sample from Loy Yang, Australia [5]. According to study [27], the moisture of Greek, Polish and Australian lignites was $50 \%, 55 \%$, and $60.5 \%$, respectively.
Loss on ignition (LOI) is one of the most widely used methods for measuring organic matter content in soils [28]. The mass loss can be due to the loss of moisture, carbon, sulfur, and so forth, from the decomposition or combustion of the residue [29]. The LOI value of brown coal was lower as compared to LOI values of the studied biochars.

It is known that the coal-substances originated primarily from plants through a series of evolutionary changes. The plant matter is transformed sequentially into humic acid, peat, lignite (brown coal), subbituminous coal, bituminous coal, and anthracite. During those transformations, the carbon content increases while the oxygen content decreases. Thus, the precise chemical composition of coal substances is unknown because it may be derived from a variety of sources by numerous combinations of physico-chemical processes which lead to variations of mixtures of carboncontaining compounds [30]. Coals consist of broad range of substances. Owning their origin to the partial decomposition and chemical conversion, brown coal contains organic matter in a complex, porous, three-dimentional network which varies depending on deposit from one location to another. Humic substances are defined as a soluble (extractable) fraction of organic matter and they are the main components of the organic portion of brown coal [31]. They can be obtained by alkaline extraction of brown coals or leonardites. The total humic acids can be obtain by extraction with the alkaline pyrophosphate solution and free humic acids can be obtained by extraction with sodium hydroxide and the methods were used in our research. Brown coal sample was characterized by the relatively high free humic acid values
Table 5 Physico-chemical properties of brown coal and biochars

\begin{tabular}{llllll}
\hline Parametr & Unit & Brown coal & Biochar 1 & Biochar 2 & Biochar 3 \\
\hline $\mathrm{pH}_{\mathrm{H}_{2} \mathrm{O}}, \mathrm{AR}$ & - & 4.3 & 10.3 & 9.6 & 7.4 \\
Electrical conductivity (EC), AR & $\mu \mathrm{S} \mathrm{cm}^{-1}$ & 1362 & 2190 & 353 & 483 \\
Loss on ignition (LOI), $550^{\circ} \mathrm{C} ; 3.5 \mathrm{~h}, \mathrm{DM}$ & $\mathrm{wt} \%$ & 84.45 & 87.28 & 94.89 & 95.99 \\
Water content, $105{ }^{\circ} \mathrm{C}, 4 \mathrm{~h}, \mathrm{AR}$ & $\mathrm{wt} \%$ & 47.70 & 45.64 & 5.98 & 3.09 \\
$\mathrm{~Pb}, \mathrm{DM}$ & $\mathrm{mg} \mathrm{kg}^{-1}$ & $<4.0$ & $<4.0$ & $<4.0$ & - \\
$\mathrm{Cd}, \mathrm{DM}$ & $\mathrm{mg} \mathrm{kg}^{-1}$ & $<1.0$ & 1.58 & $<1.0$ & - \\
Total humic acids, DM & $\mathrm{wt} \%$ & 51.02 & 6.50 & 6.89 & - \\
Free humic acids, DM & $\mathrm{wt} \%$ & 49.20 & 4.49 & 3.44 & - \\
$\mathrm{C}, \mathrm{DM}$ & $\mathrm{wt} \%$ & 53.46 & $63.5 *$ & 85.80 & 84.44 \\
$\mathrm{H}, \mathrm{DM}$ & $\mathrm{wt} \%$ & 4.42 & $0.95 *$ & 1.36 & 1.99 \\
$\mathrm{~N}, \mathrm{DM}$ & $\mathrm{wt} \%$ & 0.76 & $1.80^{*}$ & 0.74 & 0.57 \\
Molar ratio $\mathrm{H} / \mathrm{C}$ & - & 0.99 & $0.18^{*}$ & 0.19 & 0.28 \\
Water soluble $\mathrm{P}_{2} \mathrm{O}_{5}$, in ash & $\mathrm{wt} \%$ & $<0.10$ & 0.12 & $<0.10$ & $<0.10$ \\
Total $\mathrm{P}_{2} \mathrm{O}_{5}$, in ash & $\mathrm{wt} \%$ & $<0.10$ & 17.63 & 12.01 & 6.07 \\
Water soluble $\mathrm{K}_{2} \mathrm{O}$, in ash & $\mathrm{wt} \%$ & $<0.10$ & 1.10 & 0.26 & $<0.10$ \\
Total $\mathrm{K}_{2} \mathrm{O}$, in ash & $\mathrm{wt} \%$ & 0.23 & 25.45 & 19.65 & 8.27 \\
\hline
\end{tabular}

$D M$ dry matter, $A R$ as received, - not determined

*Results from biochar certificate 
(> 50\%). Research showed that humic acids occur naturally in lignite and can account from 10 to $80 \%$ depending on the maturity level of the lignite organic matter [31, 32]. For example, the content of humic acids in Greek leonardites was below $20 \%$ and seldom below $30 \%$. While, American leonardites were characterized by the high humic acid contents $(>80 \%$ ) [31]. Thus, the studied Polish brown coal can be the valuable raw material for preparing humate-based fertilizer products. Our results agree with the previous study [24]. Researchers [31] who examined European coals found that they are characterized by low contents of heavy metals. Cadmium and lead contents in brown coal were below the limits of detection. Organic elemental analysis showed that the studied brown coal was characterized by carbon content of $53.46 \mathrm{wt} \%$, hydrogen content of $4.42 \mathrm{wt} \%$, nitrogen content of $0.76 \mathrm{wt} \%$, and the $\mathrm{H} / \mathrm{C}$ molar ratio of 0.99 . The value for carbon content is slightly below the range reported in literature and the values for the contents of hydrogen and nitrogen are within the range reported in literature for the European brown coals. For example, Janos et al. [31] found that carbon content was in the range of 55.43-68.03\%, hydrogen content was in the range of 3.84-5.79\% and nitrogen content was in the range $0.71-1.86 \%$.

Biochars as organic materials can be used as components of mineral and organic fertilizers or soil amendments [32-34]. The studied biochars were alkaline ( $\mathrm{pH}$ value in the range of 7.4 to 10.3). According to literature [35], most biochars are alkaline, however, biochar $\mathrm{pH}$ values between 3.1 and 12.0 have been also reported [7, 36, 37]. Feedstock and pyrolysis temperatures are two of the most important factors affecting biochar $\mathrm{pH}$ values. For example, biochars derived from animal biomass or manures tend to have higher $\mathrm{pH}$ than biochars pyrolysed from plant species [38-40]. As most biochars (especially high-temperature and animalbiomass derived ones) are alkaline in nature [41]. Biochars produced under high temperature $\left(>400{ }^{\circ} \mathrm{C}\right)$ are likely to have greater $\mathrm{pH}$ value than the low temperature $\left(<400{ }^{\circ} \mathrm{C}\right)$ biochars from the same feedstocks [37]. The studied biochar EC values were within the ranges reported in literature [33]. The biochar EC is dependent on the feedstock and the pyrolysis temperature. Biochars produced at higher pyrolysis temperatures generally have higher EC values and this effect has been attributed the increasing concentration of residues or ash caused by the loss of volatile material during $[42,43]$. Differences in the EC of biochars produced from different feedstocks are attributed to differences in their ash contents [43]. Wood and paper waste biochars generally have lower EC values than manure biochars [44]. Alburquerque et al. [36] found that the electrical conductivity (EC) value differed greatly among samples $\left(1500 \mu \mathrm{S} \mathrm{cm}^{-1}\right.$ for olive tree pruning biochar and $2800 \mu \mathrm{S} \mathrm{cm}^{-1}$ for wheat straw biochar). The LOI-550 representing the organic matter fractions of biochars [45]. Our results were similar to other studied biochar LOI values [46] and ranged from 87.28 to $95.99 \mathrm{wt} \%$. Soudek et al. [47] examined different biochars and found that the $\mathrm{Cd}$ content was in the range from 0.14 (rice husk biochar) to $0.26 \mathrm{mg} \mathrm{kg}^{-1}$ (ash tree biochar) and the $\mathrm{Pb}$ content in the range from 0.86 (ash tree biochar) to $3.7 \mathrm{mg} \mathrm{kg}^{-1}$ (beech tree biochar). Our results showed that the studied biochars were characterized by $\mathrm{Pb}$ content below the detection limit of $4 \mathrm{mg} \mathrm{kg}^{-1}$ and $\mathrm{Cd}$ content below $1 \mathrm{mg} \mathrm{kg}^{-1}$, except for the medical plant biochar sample that was characterized by $\mathrm{Cd}$ content of $1.59 \mathrm{mg} \mathrm{kg}^{-1}$. $\mathrm{Pb}$ and $\mathrm{Cd}$ are elements dominantly extracted from inorganic component of lignite [48]. Moreover, the authors [48] pointed out that the elements are differently distributed and can be divided into groups based on the difference of their extractability in the particular phase of the sequential extraction of the coal. The average concentration of $\mathrm{Pb}$ was $14.91 \mathrm{mg} \mathrm{kg}^{-1}$ and the concentration of $\mathrm{Cd}$ was $0.10 \mathrm{mg} \mathrm{kg}^{-1}$ in the 5 th phase of the sequential extraction of the eight milled lignite samples [48].

The examined biochars were characterized by low contents of humic substances (up to $6.89 \mathrm{wt} \%$ of total humic acids). According to research conducted by Zhang et al. [49] the wood biochar sample was found to have the most humification materials (fulvic acid-like and humic acid-like materials) in the water-extractable fraction, which was 3-10 times higher than that in the rice husk biochar and rice husk ash while humified materials were not detected in the bamboo biochar sample.

Organic elemental analysis showed that biochars contained total carbon in the range of 63.5 to $85.80 \mathrm{wt} \%$. For example, pine biochar was characterized by the total $\mathrm{C}$ content of $79.34 \%$ and corn cob biochar by the total $\mathrm{C}$ content of $78.58 \%$. Hydrogen contents in the studied biochars ranged from 0.95 to $1.99 \%$ and nitrogen contents from 0.57 to $1.80 \%$. For example, the total $\mathrm{N}$ content in pine biochar was $0.02 \%$ and in corn cob biochar was $0.68 \%$ and the total $\mathrm{H}$ content in the mentioned above biochars was 1.22 and $1.91 \%$, respectively [46]. Moreover, the $\mathrm{H} / \mathrm{C}$ molar ratio (ranged from 0.18 to 0.28 ) in the studied biochars was similar to results $(0.18$ for pine biochar and 0.28 for corn cob biochar) obtained in other study [46].

Biochar ashes were characterized by high amounts of total $\mathrm{P}_{2} \mathrm{O}_{5}$ contents (from 6.07 to $17.63 \mathrm{wt} \%$ ) and total $\mathrm{K}_{2} \mathrm{O}$ contents (from 8.27 to $25.45 \mathrm{wt} \%$ ). In the other research study [50], it was found that wood ash contained total $\mathrm{P}_{2} \mathrm{O}_{5}$ of $3.89 \%$ and total $\mathrm{K}_{2} \mathrm{O}$ of $9.5 \%$.

\section{Laboratory Pan Granulation}

Table 6 shows the moisture content and the $\mathrm{pH}$ value of the brown coal based fertilizer product produced in the pan granulator on laboratory scale. The moisture content of the fertilizer product sample was $30.2 \%$. The $\mathrm{pH}$ value of 
Table 6 Moisture content (\%) and $\mathrm{pH}$ value of brown coal based fertilizer product (laboratory pan granulation)

\begin{tabular}{llc}
\hline Parameter & Unit & Result \\
\hline Moisture content & wt $\%$ & 30.2 \\
pH of air-dried sample & - & 2.4 \\
pH of dried sample at $105^{\circ} \mathrm{C}$ & - & 3.7 \\
\hline
\end{tabular}

samples was acidic (2.4-3.7\%). The fertilizer product was too acidic to use it in further pot trials because of the future soil acidification and the negative impact on a plant growth development. According to the study, more research should be done to increase the $\mathrm{pH}$ value of the final fertilizer product, e.i. study on the addition of alkaline raw materials.

Particle hardness measured as Newtons (N) refers to the amount of force that particles can withstand before rupturing [51]. This parameter was determined in the fertilizer product after drying at $105^{\circ} \mathrm{C}$ for $3 \mathrm{~h}$. The brown coal based fertilizer granules were characterized by very low particle hardness. All of the granules $(100 \%)$ were classified as weak granules. For the average size of granules of $4.26 \mathrm{~mm}$, the average hardness was $2.3 \mathrm{~N}$. The granules were classified as "soft" because they very easy crushed between the thumb and forefinger [52]. The research on binder agents and the addition of other raw materials should be studied in order to increase the particle hardness of the final fertilizer product. Rose et al. [5] conducted research on brown coal-urea blended fertilizer (urea to wet coal ratio of 1:6) that was granulated and dried in the pilot scale superheated steam drum dryer. The granule crush strength was weak (2.2-2.9 N) and our results are in agreement with the study [5].

\section{Granulation of Brown Coal Based Compound Fertilizer in Large Scale}

Because of the unsatisfactory mechanical and physical properties of fertilizer granules obtained in the laboratory scale using the pan granulation, it was decided to select the method of high shear granulation in the larger scale. The raw material consumption at the trial 1 in large scale was similar to the trial conducted in the laboratory scale (Table 7).
After conducting the trial 1 in the large scale, it was stated that granules obtained in the high shear granulation process were characterized by the better mechanical and physical properties and the granules size as compared to the pan granulation. Thus, it was decided to choose the mentioned method of granulation to study the effect of the additives on the fertilizer product quality. Moreover, during the production of fertilizer some gases can be emitted because of the reaction processes between the used raw materials (e.g. urea, phosphorite, sulfuric acid and brown coal). The mineral materials were similar to those used in urea superphosphate production. The following example reactions should be taken into the account: reaction of sulfuric acid with phosphorite, reaction of urea with sulfuric acid, reaction of mixture urea-sulfuric acid with phosphorite and brown coal, reaction between acids and ammonia etc. Phosphate rock usually contains between $3 \%$ and $4.5 \%$ of fluoride by weight [53]. During the acidulation of phosphate rock, released hydrogen fluoride is usually converted into fluosilicic acid by silica in the rock, most of which is retained in the product, but about $25 \%$ is released in production process of the phosphate fertilizers. Wet scrubbers are required for production of phosphate fertilizers. In addition, fluoride emission continues during the curing process [53]. Moreover, greenhouse gas emissions during fertilizer production occur [54]. Similarly, there can be small amounts of fertilizers released during maintenance. Thus, pollution prevention and control is needed during the fertilizer manufacture. Although, dust was not observed during the pan granulation, the rapid mixer granulator (at which a chemical reaction is carried out simultaneously) equipped with a cover is the most suitable for the granulation purposes of the studied raw materials in order to prevent possible dust and harmful emissions to workers.

At the conducted trials, the brown coal (dry mass) constituted from 45.5 to $50 \mathrm{wt} \%$ of total raw material consumption (Table 7). Water present in brown coal (wet brown coal moisture of about 50\%) was the additional amount of water in the production process of the organomineral fertilizer. At the end of granulation process, some additional amount of water was added. Table 7 shows the raw material consumption at particular trials.
Table 7 Raw material consumption for brown coal based fertilizer production

\begin{tabular}{|c|c|c|c|c|c|c|c|c|}
\hline \multirow[t]{2}{*}{ No. of trial } & \multicolumn{8}{|c|}{ Raw material consumption (wt $\%$ ) } \\
\hline & $\begin{array}{l}\text { Brown coal } \\
\text { (BC), DM }\end{array}$ & Urea & Phosphorite & $\mathrm{H}_{2} \mathrm{SO}_{4}, 100 \%$ & Dolomite (D) & $\begin{array}{l}\text { Caustic } \\
\text { magnesite } \\
\text { (M) }\end{array}$ & $\mathrm{H}_{2} \mathrm{O}$ & $\mathrm{NH}_{3}(\mathrm{~g})$ \\
\hline 1 & 50.0 & 22.8 & 16.8 & 10.4 & - & - & 2.7 & - \\
\hline 2 & 45.5 & 20.8 & 15.3 & 9.4 & 9.0 & - & 2.5 & - \\
\hline 3 & 50.0 & 22.8 & 16.8 & 10.4 & - & - & 2.7 & + \\
\hline 4 & 47.5 & 21.7 & 16.0 & 9.9 & - & 5.0 & 2.6 & - \\
\hline
\end{tabular}


Table 8 Particle hardness (N) and percentage of weak granules (\%)

\begin{tabular}{|c|c|c|c|c|c|}
\hline Parameter & Unit & Trial 1 & Trial 2 & Trial 3 & Trial 4 \\
\hline Average granule size & $\mathrm{mm}$ & 4.04 & 3.94 & 4.04 & 3.90 \\
\hline Average particle hardness & $\mathrm{N}$ & 23.30 & 18.18 & 20.05 & 15.80 \\
\hline Percentage of weak granules & $\%$ & 10 & 20 & 25 & 30 \\
\hline $\begin{array}{l}\text { Average particle hardness } \\
\text { after excluding weak } \\
\text { granules }\end{array}$ & $\mathrm{N}$ & 24.89 & 21.12 & 23.38 & 19.62 \\
\hline
\end{tabular}

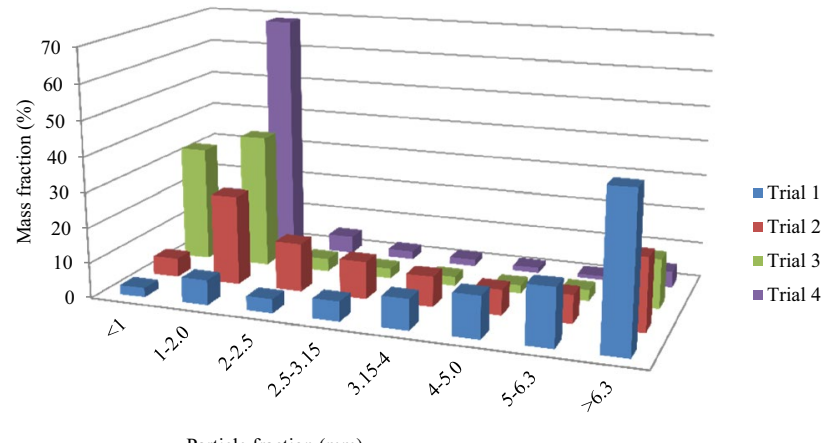

Particle fraction (mm)

Fig. 1 Sieve analysis of four granulation trials of brown coal based granular compound fertilizer

In order to determine mechanical and physical properties of the obtained fertilizer products, particle hardness and percentage of weak granules were determined (Table 8). Particle hardness of granules varied from 15.8 to 23.3 and after excluding weak granules (below $10 \mathrm{~N}$ ) varied from 19.6 to $24.9 \mathrm{~N}$. For handling purposes of fertilizers, particles hardness should be at least $13.73 \mathrm{~N}$, and of $22.56 \mathrm{~N}$ or greater is highly desirable [55]. Our results showed that particle hardness of granules was satisfactory.

Figure 1 shows the particle size distribution of the obtained fertilizer products. In trial 1 , the largest mass fraction was found in the particle size fraction $>6.3 \mathrm{~mm}$ (43.69\%). Assuming that particles $2-5 \mathrm{~mm}$ are suitable for fertilizer application a product of output of approximately $47 \%$ was achieved. In trial 2, the largest mass fraction was found in the particle size fraction $1-2 \mathrm{~mm}(25.55 \%)$. The particles $2-5 \mathrm{~mm}$ made around $49 \%$ of the total mass. In trial 3, the largest mass fraction was found in the particle size fraction 1-2 $\mathrm{mm}$ (38.19\%). The particles $2-5 \mathrm{~mm}$ made around $15 \%$ of the total mass. In trial 4 , the largest mass fraction was found in the particle size fraction 1-2 mm (69.07\%). The particles $2-5 \mathrm{~mm}$ made around $12 \%$ of the total mass. In the trials, the fractions $<1 \mathrm{~mm}$ made from $2.63 \%$ (Trial 1) to $33.01 \%$ (Trial 3) of the total mass and would be recharged into a mixer to the new batch. The oversized grains $>6.3 \mathrm{~mm}$ made from $4.7 \%$ (Trial 4 ) to $43.69 \%$ (Trial 1) of the total mass and would possibly be crushed and added to the product.

Photographs of granules produced in the rapid mixer granulator are shown in Fig. 2. The products were spherical granules with smaller coarse surface particles attached.

The chemical properties of the obtained brown coal based fertilizer granules were evaluated (Table 9). The moisture content of granules varied from 25.7 to $29 \%$. The $\mathrm{pH}$ values of granules from trials 1 and 2 was acidic and amounted 2.6 and 3.3, respectively. The $\mathrm{pH}$ values of granules from trials 3 and 4 were higher and amounted 5.4 and 6.2, respectively. The addition of dolomite, gaseous ammonia and caustic magnesite increased the $\mathrm{pH}$ of the final products. Only granules from trials 3 and 4 were used for further pot trials because of the most appropriate $\mathrm{pH}$ value for soil and plants. Brown coal based fertilizers contained from 8.26 to $9.85 \%$ of total nitrogen, from 3.67 to 4.39 of total phosphorus $\left(\mathrm{P}_{2} \mathrm{O}_{5}\right)$, from 2.86 to $3.72 \%$ of neutral ammonium citrate soluble phosphorus $\left(\mathrm{P}_{2} \mathrm{O}_{5}\right)$, and from 0.69 to $2.60 \%$ of water soluble phosphorus $\left(\mathrm{P}_{2} \mathrm{O}_{5}\right)$. The plant available phosphorus in granules constituted from 62 (trial 2) to $84.7 \%$ (trial 1) of total phosphorus and water soluble phosphorus constituted from 18.2 (trial 4) to $59.2 \%$ (trial 1) of total phosphorus present in fertilizer granules.

Dolomite (trial 2) and caustic magnesite (trial 4) as components of fertilizer formulations were sources of $\mathrm{Mg}$ and Ca. Granules from the trial 2, contained $1.18 \%$ of $\mathrm{Mg}$ and
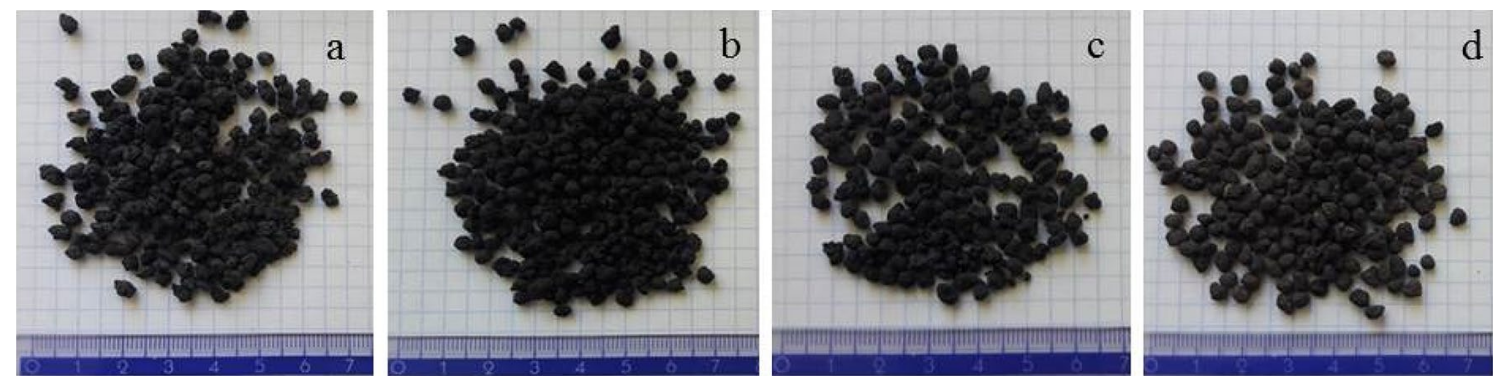

Fig. 2 Brown coal based fertilizer granules (fraction 2.5-3.15 mm) prepared with a rapid mixer granulator: $\mathbf{a}-$ Trial 1: BC+USP, $\mathbf{b}-$ Trial 2: $\mathrm{BC}+\mathrm{USP}+\mathrm{D}, \mathbf{c}-$ Trail 3: $\mathrm{BC}+\mathrm{USP}+\mathrm{NH} 3, \mathbf{d}-$ Trial 4: $\mathrm{BC}+\mathrm{USP}+\mathrm{M}$ 
Table 9 Chemical properties of brown coal based fertilizers

\begin{tabular}{|c|c|c|c|c|c|}
\hline Parameter & Unit & $\begin{array}{l}\text { Trial } 1 \\
\mathrm{BC}+\mathrm{USP}\end{array}$ & $\begin{array}{l}\text { Trial } 2 \\
\mathrm{BC}+\mathrm{USP}+\mathrm{D}\end{array}$ & $\begin{array}{l}\text { Trial } 3 \\
\mathrm{BC}+\mathrm{USP}+\mathrm{NH}_{3(\mathrm{~g})}\end{array}$ & $\begin{array}{l}\text { Trial } 4 \\
\mathrm{BC}+\mathrm{USP}+\mathrm{M}\end{array}$ \\
\hline Moisture content $\left(105^{\circ} \mathrm{C} ; 3 \mathrm{~h}\right)$ & $\mathrm{wt} \%$ & 29.0 & 25.7 & - & - \\
\hline Moisture content $\left(90^{\circ} \mathrm{C} ; 1 \mathrm{~h}\right)$ & $\mathrm{wt} \%$ & - & - & 9.3 & 8.3 \\
\hline $\mathrm{pH}$ & - & 2.6 & 3.3 & 5.4 & 6.2 \\
\hline Ntot & wt $\%$ & 9.85 & 9.83 & 9.58 & 8.26 \\
\hline $\mathrm{P}_{2} \mathrm{O}_{5}$ tot & $\mathrm{wt} \%$ & 4.39 & 3.76 & 3.85 & 3.67 \\
\hline $\mathrm{NAC}+\mathrm{H}_{2} \mathrm{O}$ soluble $\mathrm{P}_{2} \mathrm{O}_{5}$ & $\mathrm{wt} \%$ & 3.72 & 3.21 & 3.03 & 2.86 \\
\hline $\mathrm{H}_{2} \mathrm{O}$ soluble $\mathrm{P}_{2} \mathrm{O}_{5}$ & wt $\%$ & 2.60 & 2.33 & 1.77 & 0.69 \\
\hline $\mathrm{Mg}$ & $\mathrm{wt} \%$ & 0.11 & 1.18 & 0.11 & 1.63 \\
\hline $\mathrm{Ca}$ & wt $\%$ & 6.28 & 8.37 & 5.20 & 5.37 \\
\hline \multicolumn{6}{|l|}{ Loss on ignition } \\
\hline $105^{\circ} \mathrm{C}$ & $\mathrm{wt} \%$ & 31.32 & 28.70 & 31.50 & 30.20 \\
\hline $400{ }^{\circ} \mathrm{C}$ & $\mathrm{wt} \%$ & 72.54 & 64.55 & 74.53 & 70.67 \\
\hline $1000^{\circ} \mathrm{C}$ & wt $\%$ & 81.91 & 73.98 & 82.61 & 77.64 \\
\hline
\end{tabular}

$\mathrm{NAC}+\mathrm{H}_{2} \mathrm{O}-$ neutral ammonium citrate and water soluble
$8.37 \%$ of $\mathrm{Ca}$. Granules from the trial 4 contained $1.63 \%$ of $\mathrm{Mg}$ and $5.37 \%$ of $\mathrm{Ca}$. Loss on ignition (LOI) of fertilizer granules at $105{ }^{\circ} \mathrm{C}$ varied from 28.7 to $31.5 \%$, at $400{ }^{\circ} \mathrm{C}$ varied from 64.55 to $74.53 \%$, and at $1000{ }^{\circ} \mathrm{C}$ varied from 73.98 to $82.61 \%$. LOI is a common and widely used method to estimate the organic and carbonate content of sediments. In a first reaction, organic matter is oxidized at $500-550{ }^{\circ} \mathrm{C}$ to carbon dioxide and ash. In a second reaction, carbon dioxide is evolved from carbonate at $900-1000{ }^{\circ} \mathrm{C}$, leaving oxide. The weight loss during the reactions is closely correlated to the organic matter and carbonate content [56].

\section{Hygroscopicity of Brown Coal, Biochar and the Selected Brown Coal Based Fertilizers}

Hygroscopicity is the ability of a material to absorb or adsorb moisture from surrounding environment [57]. This property of solid raw materials and the final solid fertilizer products is often evaluated due to the fact that the up-taken moisture can impact physical and chemical stability of the fertilizer products.

Figure 3 presents the hygroscopicity measurements of biochar, brown coal, and brown coal based fertilizers. It was found that biochar sample (B3), stored under the relative humidity of $56-74 \%$, absorbed water in the amount of $5 \%$ by mass. Biochars are porous materials and their pore structure has the effects on the water absorption and water retention properties [58]. Gray et al. [59] stated that water uptake by biochars is dependent on both feedstock, which controls residual macroporosity and production temperature, which controls hydrophobicity and pyrogenic nanopore formation. Brown coal, stored under the relative humidity of $74 \%$ for 7 days, lose water in the amount of about $34 \%$ by mass. Brown coal based fertilizers, stored under the relative humidity of

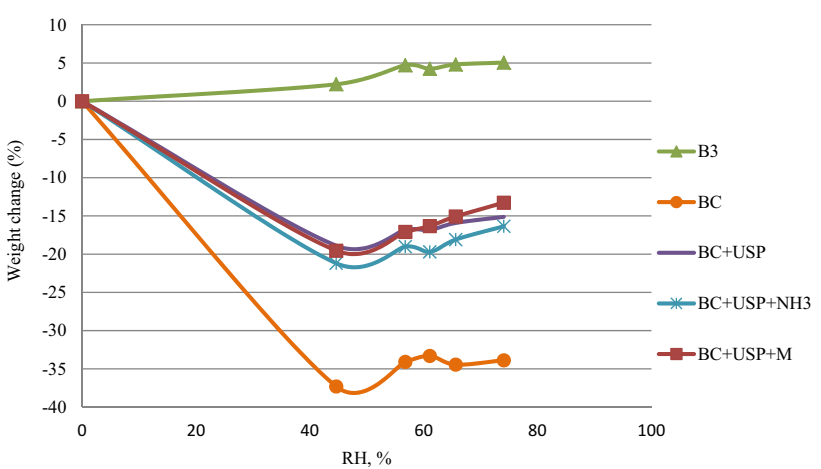

Fig. 3 Hygroscopicity measurments of biochar, brown coal, and brown coal based fertilizers, demonstrating the weight change (\%) as a function of the relative humidity $(\%)$ for each sample (sorption isotherm)

$74 \%$ for 7 days, lose water in the amounts of $13-16 \%$ by mass. It was found that brown coal and brown coal based fertilizers underwent a natural drying process. According to other research, the affinity of pure carbon for water is low due to the unusually weak non-specific interactions between the non-polar surface and the highly polar character of this adsorbate [60, 61].

\section{Biochar Coated Fertilizer}

Table 10 shows the physical properties of USP and biochar coated USP fertilizer granules. Average particle hardness of biochar coated USP was lower (from 41.65 to 49.50 ) as compared to USP granules before coating $(61.90 \mathrm{~N})$. It was found that the type of biochar used for coating process had the influence on abrasion resistance of granules which varied from 2.5 to $7.8 \%$. Figure 4 shows urea superphosphate and 
Table 10 Particle hardness $(\mathrm{N})$ and abrasion resistance of biochar coated fertilizer

\begin{tabular}{llcccc}
\hline Parameter & Unit & USP & B1 coated USP & B2 coated USP & B3 coated USP \\
\hline Average granule size & $\mathrm{mm}$ & 4.46 & 4.46 & 4.16 & 4.28 \\
Average particle hardness & $\mathrm{N}$ & 61.90 & 41.65 & 45.20 & 49.50 \\
Abrasion resistance & $\%$ & 0.7 & 2.5 & 6.1 & 7.8 \\
\hline
\end{tabular}
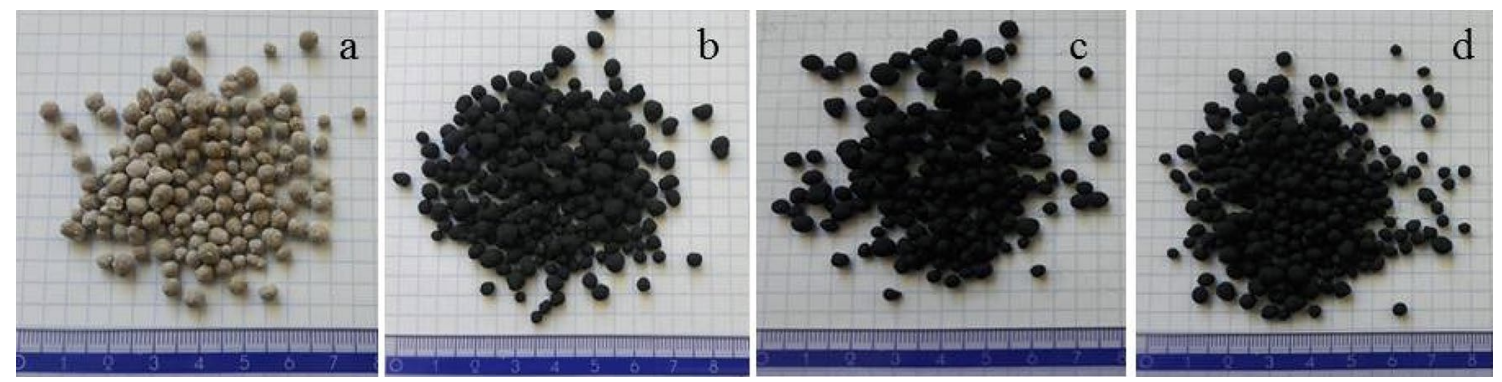

Fig. 4 Urea superphosphate and biochar coated fertilizer granules prepared in a pan granulator: $\mathbf{a}-\mathrm{USP}, \mathbf{b}-\mathrm{B} 1$ coated USP, $\mathbf{c}-\mathrm{B} 2$ coated USP, d-B3 coated USP

biochar coated fertilizer granules photographs. The coating of USP granules with biochar and water as the binder worked very well. Binders are responsible for a good adhesion of the coating to the substrate. Chen et al. [62] used biochar waterborne copolymer of polyvinyl alcohol and polyvinylpyrrolidone as coating materials for urea. The abovementioned study has showed the potential of biochar-based copolymer to improve the effectiveness of fertilizers. Moreover, researchers [62] stated that biochar decreased water absorbency of copolymer with an increased degradability, and contributed to improving the slow release property of coated urea. Chen et al. [62] found that the rice biocharbased copolymer coated urea showed excellent slow-release performance of $65 \%$ nutrient leaching at the end of leaching test.

\section{Pot Trials}

Table 11 shows the yield, spike number and plant height of spring wheat cv. Varius. According to the conducted statistical analysis, the highest grain yield per plant was stated when wood chips biochar coated USP fertilizer $\left(T_{7}\right)$ was applied as compared to commercial fertilizer $\left(\mathrm{T}_{2}\right)$ and medicinal plant biomass biochar coated USP fertilizer $\left(\mathrm{T}_{5}\right)$. There were no significant influence of the studied fertilizer type on spike number per plant and plant height measured at the booting stage of wheat development. Results from this study showed that spring wheat responded positively to soil application of the brown coal based fertilizers and biochar coated fertilizers. Similar results were found by Ali et al. [63], who studied the effect of biochar, farmyard manure and nitrogen (organic and inorganic soil amendments) on growth and quality of spring wheat and determined that the
Table 11 Grain yield per plant, spike number per plant, and plant height of spring wheat cv. Varius (2018)

\begin{tabular}{llll}
\hline Treatment & $\begin{array}{l}\text { Grain yield per } \\
\text { plant }(\mathrm{g})\end{array}$ & $\begin{array}{l}\text { Spike number per } \\
\text { plant }(\mathrm{pc})\end{array}$ & $\begin{array}{l}\text { Plant } \\
\text { height } \\
(\mathrm{cm})\end{array}$ \\
\hline $\mathrm{T}_{0}$ & $4.36 \mathrm{ab}$ & 3.9 & 51 \\
$\mathrm{~T}_{1}$ & $3.39 \mathrm{abc}$ & 2.5 & 50 \\
$\mathrm{~T}_{2}$ & $2.94 \mathrm{bc}$ & 2.5 & 50 \\
$\mathrm{~T}_{3}$ & $3.90 \mathrm{abc}$ & 3.0 & 57 \\
$\mathrm{~T}_{4}$ & $3.73 \mathrm{abc}$ & 2.8 & 56 \\
$\mathrm{~T}_{5}$ & $2.62 \mathrm{c}$ & 2.5 & 55 \\
$\mathrm{~T}_{6}$ & $3.71 \mathrm{abc}$ & 2.5 & 53 \\
$\mathrm{~T}_{7}$ & $4.56 \mathrm{a}$ & 3.3 & 52 \\
$\mathrm{LSD}_{0.05}$ & 1.59 & n.s & n.s \\
\hline
\end{tabular}

n.s. not significant at 0.05

biochar treatments could significantly improve wheat leaf, stem, straw and grain $\mathrm{N}$ and protein content. Researchers [63] have recommended biochar in combination with farmyard manure and mineral $\mathrm{N}$ in cereal-cereal cropping pattern in Pakistan to preserve soil, prevent soil degradation, and improve soil and crop quality. Reibe et al. [64] found that yield, yield components and quality were mainly influenced by nitrogen fertilizer. The application of maize hydro-char could have negative effects on yield and yield components of spring wheat while hydro-char treated with digestate had no negative effects on yield of spring wheat. Alburquerque et al. [36] found that the addition of biochar alone had the positive effect on some growth parameters but clearly lower when compared to the use of the mineral fertilization. Moreover, they stated the significant biochar $\times$ mineral fertilization interaction since the highest grain production was 
obtained when biochars were combined with the complete mineral fertilization, demonstrating the beneficial effect of biochar on wheat yield. According to the study biochar had much influence on soil properties, which can explain its effects on plant growth and grain production. Studied biochars [36] caused significant increases in soil $\mathrm{pH}$, electrical conductivity, and resin-extractable phosphate. However, the application of biochar decreased resin-extractable ammonium and nitrate. The most relevant effect on plant nutrition was a decrease in $\mathrm{N}$ and especially in $\mathrm{Mn}$ plant uptake, which can limit crop performance in the long term. Therefore, the nutrient-biochar interactions should receive special attention. Biochar addition can enhance wheat yield with the environmental benefits of global warming mitigation, contributing to a more sustainable agriculture [36]. In addition, biochar itself does not contain enough nutrients for crop growth. Asai et al. [65] found that grain yield decreased when applying only biochar due to the insufficient supply of nitrogen. Thus, application of biochar with certain fertilizers (for example urea) or the use as a fertilizer component renders biochar materials more suitable for stimulating plant growth and heavy metal adsorption.

\section{Conclusions}

In summary, brown coal and biochar can be used as raw materials for fertilizer production. Brown coal contained about $50 \%$ of total humic acids while biochar contained nearly $6 \%$ of total humic-like substances. Brown coal based fertilizer produced in laboratory scale using a pan granulator were classified as 'soft'. Additional studies should be conducted to select a special binder and appropriate raw material ratios to increase the particle hardness. The scale up of the granulation process and the use the high shear granulation had the positive influence on the final product quality. Brown coal based fertilizer granules produced in large scale using the rapid mixer granulator were characterized by promising hardness and particle size distribution. The formed granules were of an appropriate size and sufficiently strong for agricultural use. Biochar can be used for the coating purposes of urea superphosphate fertilizer but additional studies are necessary to select the special binding agent in order to reduce abrasion resistance of granules. Results from pot experiments in greenhouse showed that spring wheat responded positively to soil application of the brown coal based fertilizers and biochar coated fertilizers.

Acknowledgements This work is financially supported by the National Centre for Research and Development of Poland under Grant No. BIOSTRATEG3/347464/5/NCBR/2017.

Open Access This article is distributed under the terms of the Creative Commons Attribution 4.0 International License (http://creativeco mmons.org/licenses/by/4.0/), which permits unrestricted use, distribution, and reproduction in any medium, provided you give appropriate credit to the original author(s) and the source, provide a link to the Creative Commons license, and indicate if changes were made.

\section{References}

1. Sleutel, S., De Neve, S., Hofman, G.: Estimates of carbon stock changes in Belgian cropland. Soil Use Manage. 19, 166-171 (2003)

2. Jones, R.J.A., Hiederer, R., Rusco, E., Montanarella, L.: Estimating organic carbon in the soils of Europe for policy support. Eur. J. Soil Sci. 56, 655-671 (2005)

3. Allard, B.: A comparative study on the technical composition of humic acids from forest soil, agricultural soil and lignite deposit; Bound lipid, carbohydrate and amino acid distributions. Geoderma 130, 77-96 (2006)

4. Ouni, Y., Ghnaya, T., Montemurro, F., Abdelly, Ch, Lakhdar, A.: The role of humic substances in mitigating the harmful effects of soil salinity and improve plant productivity. Intl J. Agron. Plant Prod 8(3), 353-374 (2014)

5. Rose, M.T., Perkins, E.L., Saha, B.K., Tang, E.C., Cavagnaro, T.R., Jackson, W.R., Hapgood, K., Hoadley, A.F.A., Patti, A.F.: A slow release nitrogen fertiliser produced by simultaneous granulation and superheated steam drying of urea with brown coal. Chem. Biol. Technol. Agric. 3, 1-14 (2016)

6. Saha, B.K., Rose, M.T., Wong, V.N.L., Cavagnaro, T.R., Patti, A.F.: A slow release brown coal-urea fertiliser reduced gaseous $\mathrm{N}$ loss from soil and increased silver beet yield and $\mathrm{N}$ uptake. Sci. Tot. Environ. 649, 793-800 (2019)

7. Lehmann, J.: Bio-Energy in the Black. Front. Ecol. Environ. 5, 381-387 (2007)

8. Kwapinski, W., Byrne, C.M.P., Kryachko, E., Wolfram, P., Adley, C., Leahy, J.J., Novotny, E.H., Hayes, M.H.B.: Biochar from biomass and waste. Waste Biomass Valoriz. 1(2), 177-189 (2010)

9. Azis, N.S.A., Nor, M.A.M., Manaf, S.F.A., Hamzah, F.: Suitability of biochar produced from biomass waste as soil amendment. Procedia Soc. Behav. Sci. 195, 2457-2465 (2015)

10. Lin, Y., Munroe, P., Joseph, S., Henderson, R., Ziółkowski, A.: Water extractable organic carbon in untreated and chemical treated biochars. Chemosphere. 87, 151-157 (2012)

11. Manikandan, A., Subramanian, K.S.: Urea intercalated biochar - a slow release fertilizer production and characterisation. Indian. J. Sci. Technol. 6(12), 5579-5584 (2013)

12. Saha, B.K., Rose, M.T., Wong, V., Cavagnaro, T.R., Patti, A.F.: Hybrid brown-coal fertiliser reduces nitrogen loss compared to urea alone. Sci. Total Environ. 601-602, 1496-1504 (2017)

13. Sempeho, S.J., Kim, H.T., Mubofu, E., Hilonga, A.: Meticulous overview on the controlled release fertilizers. Adv. Chem. (2014). https://doi.org/10.1155/2014/363071

14. Kallenbach, C., Grandy, A.S.: Controls over soil microbial biomass responses to carbon amendments in agricultural systems: a meta-analysis. Agric. Ecosyst. Environ. 144, 241-252 (2011)

15. Lehmann, J., Rillig, M.C., Thies, J., Masiello, C.A., Hockaday, W.C., Crowley, D.: Biochar effects on soil biota-a review. Soil Biol. Biochem. 43, 1812-1836 (2011)

16. Biskupski, A., Borowik, M., Dawidowicz, M., Igras, J., Kowalski, Z., Kruk, J., et al.: Method and plant for continuous manufacture of granular USP nitrogen and phosphate type fertilizers and products on their basis. EP Appl. (2014)

17. ISO 10390:2005. Soil quality-determination of $\mathrm{pH}$

18. ISO 11265:1994. Soil quality-determination of the specific electrical conductivity 
19. ISO 5073:2013. Brown coals and lignites-determination of humic acids

20. PN-EN 1235:1999. Solid Fertilizers - Test Sieving (1999)

21. Regulation, (E.C.): No 2003/2003 of the European Parliament and of the Council of 13 October 2003 relating to fertilisers. Official Journal of the European Union. L 304 (2003)

22. Large, E.C.: Growth stages in cereals-illustration of the Feekes scale. Plant Pathol. 3, 128-129 (1954)

23. Zhu, H., Qin, Y., Ma, L., Zhang, M., Zhao, Y., Li, B., Zhang, H.: Analysis of the volatile components of brown coal distillate using the headspace extraction-GC-MS. J. Chem. Pharm. Res. 6(7), 2456-2459 (2014)

24. Hoffmann, K., Huculak-Mączka, M.: The utilization possibility of waste lignite as a raw material in the process of obtaining humic acids preparations. Pol. J. Chem. Technol. 14(4), 1-6 (2012)

25. Hulisz, P.: Quantitative and qualitative differentiation of soil salinity in Poland. Ber. Dtsch. Bodenkd. Ges. 1, 1-4 (2008)

26. Wiatrowska, K., Komisarek, M., Marcinek, J., Kozłowski, J.: M.: Evaluation of the soil quality in the vicinityof Inowrocław soda plants. Arch. Environ. Prot. 44(3), 58-67 (2018)

27. Krawczykowska, A., Marciniak-Kowalska, J.: Problems of water content in lignites - methods of its reduction. AGH J. Min. Geoeng. 36(4), 57-65 (2012)

28. Schulte, E.E., Hopkins, B.G.: Estimation of soil organic matter by weight loss-on-ignition. In: Magdoff, F.R., Tabatabai, M.A., Hanlon Jr., E.A. (eds.) Soil Organic Matter: Analysis and Interpretation, pp. 21-31. Madison, Wisc. (1996) SSSA

29. ASTM International D7348-13: Standard Test Methods for Loss on Ignition (LOI) of Solid Combustion Residues (2013)

30. Harris, R.L., Simons, L.H., Lagowski, J.J.: The dissolution of lignite in anhydrous liquid ammonia. Conf. Paper 25(1), 264-272 (1979)

31. Janos, P., Zavodska, L., Leśny, j, Krizenecka, S., Synek, V., Hejda, S., Kubu, M.: Young brown coals for environmental applications: composition, acid-base, ion-exchange, and sorption properties of selected Central European coals. In: Steward, J.J. (Ed.) Coal Extraction, pp. 71-89, Nova Science Publishers Inc., New York (2011)

32. Czekała, W., Jeżowska, A., Chełkowski, D.: The use of biochar for the production of organic fertilizers. J. Ecol. Eng. 20(1), 1-8 (2019). https://doi.org/10.12911/22998993/93869

33. Bonanomi, G., Ippolito, F., Cesarano, G., Nanni, B., Lombardi, N., Rita, A., Saracino, A., Scala, F.: Biochar as plant growth promoter: better off alone or mixed with organic amendments? Front. Plant Sci. 8(1570), 1-12 (2017)

34. Glaser, B., Wiedner, K., Seelig, S., Schmidt, H.P., Gerber, H.: Biochar organic fertilizers from natural resources as substitute for mineral fertilizers. Agron. Sustain. Dev. 35, 667-678 (2015). https://doi.org/10.1007/s13593-014-0251-4

35. Mukherjee, A., Lal, R.: The biochar dilemma. Soil Res. (2014). https://doi.org/10.1071/SR13359

36. Alburquerque, J.A., Salazar, P., Barrón, V., Torrent, J., Campillo, D., Gallardo, M.D.C., Villar, A.: R.: Enhanced wheat yield by biochar addition under different mineral fertilization levels. Agron. Sustain. Dev. 33(3), 475-484 (2013)

37. Mukherjee, A., Zimmerman, R., Harris, W.: Surface chemistry variations among a series of laboratory-produced biochars. Geoderma 163, 247-255 (2011)

38. Novak, J.M., Lima, J., Xing, B., Gaskin, J.W., Steiner, C., Das, K.C., Ahmedna, M., Rehrah, D., Watts, D.W., Busschner, W.J., Schomberg, H.: Characterization of designer biochar produced at different temperatures and their effects on a loamy sand. Ann. Environ. Sci. 3, 195-206 (2009)

39. Singh, B., Singh, B.P., Cowie, A.L.: Characterisation and evaluation of biochars for their application as a soil amendment. Soil Res. 48(7), 516-525 (2010)
40. Spokas, K.A., Novak, J.M., Stewart, C.E., Cantrell, K.B., Uchimiya, M., Dusaire, M.G., Ro, K.S.: Qualitative analysis of volatile organic compounds on biochar. Chemosphere 85(5), 869-882 (2011)

41. Lehmann, J., Joseph, S.: Biochar for environmental management: an introduction. In: Lehmann, J., Joseph, S. (eds.) Biochar for Environmental Management: Science and Technology, pp. 1-12. International Biochar Initiative, Westerville (2009)

42. Cantrell, K.B., Hunt, P.G., Uchimiya, M.: Impact of pyrolysis temperature and manure source on physicochemical characteristics of biochar. Bioresour. Technol. 107, 419-428 (2012)

43. Rehrah, D., Reddye, M.R., Novak, J.M., Bansode, R.R., Schimmel, K.A., Yu, J., Watts, D.W., Ahmedna, M.: Production and characterization of biochars from agricultural by-products for use in soil quality enhancement. J. Anal. Appl. Pyrolysis. 108, 301-309 (2014). https://doi.org/10.1016/j.jaap.2014.03.008

44. Rajkovich, S., Enders, A., Hanley, K., Hyland, C., Zimmerman, A.R., Lehmann, J.: Corn growth and nitrogen nutrition after additions of biochars with varying properties to a temperate soil. Biol. Fertil. Soils 48, 271-284 (2012)

45. Gustafsson, Ö, Haghseta, F., Chan, C., Macfarlane, J., Gschwend, P.M.: Quantification of the dilute sedimentary soot phase: implications for PAH speciation and bioavailability. Environ. Sci. Technol. 31, 203-209 (1997)

46. Raya-Moreno, I., Rosa Cañizares, R., Domene, X., Carabassa, X., Alcañiz, V.: J.M.: Comparing current chemical methods to assess biochar organic carbon in a Mediterranean agricultural soil amended with two different biochars. Sci. Tot. Environ. 598, 604-618 (2017)

47. Soudek, P., Valseca, I.M.R., Petrová, Š, Song, J., Vaněk, T.: Characteristics of different types of biochar and effects on the toxicity of heavy metals to germinating sorghum seeds. J. Geochem. Explor. 182, 157-165 (2017)

48. Popovic, A., Djordjevic, D.: Distribution of trace and major elements in lignite and products of its combustion-leaching experiments and cluster analysis. In: Burcu Ozkaraova Gungor, E. (Ed.) Environmental Technologies: New Developments, pp. 135-146. I-Tech Education and Publishing, Vienna (2008)

49. Zhang, J., Lü, F., Luo, C., Shao, L., He, P.: Humification characterization of biochar and its potential as a composting amendment. J. Environ. Sci. 26(2), 390-397 (2014)

50. Reed, E.Y., Chadwick, D.R., Hill, P.W., Jones, D.L.: Critical comparison of the impact of biochar and wood ash on soil organic matter cycling and grassland productivity. Soil Biol. Biochem. 110, 134-142 (2017)

51. Fulton, J.: Physical properties of granular fertilizers and impact on spreading. https://ohioline.osu.edu/factsheet/fabe-5501 (2012). Accessed 04 June 2018

52. United Nations Industrial Development Organization (UNIDO) and International Fertilizer Development Center (IFDC). Fertilizer manual. Kluwer Academic Publishers, New York (1998)

53. International Fertilizer Development Center (IFDC): Part Five, Planning and economics. Pollution control and other environmental factors. In: Hignett, T.P. (Ed.): Fertilizer Manual, Developments in Plant and Soil Science, vol. 15, pp. 319-328, Springer Science + Business Media, B.V., Singapore (1985)

54. Zhang, W.F.1, Dou, Z.X., He, P., Ju, X.T., Powlson, D., Chadwick, D., Norse, D., Lu, Y.L., Zhang, Y., Wu, L., Chen, X.P., Cassman, K.G., Zhang, F.S..: New technologies reduce greenhouse gas emissions from nitrogenous fertilizer in China. Proc. Natl. Acad. Sci. USA 110(21):8375-8380 (2013). https://doi. org/10.1073/pnas.1210447110

55. Hignett, T.P.: Physical and chemical properties of fertilizers and methods for their determination. In: Hignett, T.P. (ed.) Fertilizer Manual, pp. 284-316. Springer, Dordrecht (1985) 
56. Heiri, O., Lotter, A.F., Lemcke, G.: Loss on ignition as a method for estimating organic and carbonate content in sediments: reproducibility and comparability of results. J. Paleolimnol. 25, 101$110(2001)$

57. Allada, R., Maruthapillai, A., Palanisamy, K., Chappa, P.: Hygroscopicity categorization of pharmaceutical solids by gravimetric sorption analysis: a systematic approach. Asian J. Pharm. 10(4), 279 (2016)

58. Hyväluoma, J., Kulju, S., Hannula, M., Wikberg, H., Kalli, A., Rasa, K.: Quantitative characterization of pore structure of several biochars with 3D imaging. Environ. Sci. Pollut. Res. 25, 25648 25658 (2018)

59. Gray, M., Johnson, M.G., Dragila, M.I., Kleber, M.: Water uptake in biochars: The roles of porosity and hydrophobicity. Biomass Bioenergy. 61, 196-205 (2014)

60. Sing, K.S.W.: Adsorption by active carbons. In: Rouquerol, F., Rouquerol, J., Sing, K. (eds.) Adsorption by powders and porous solids, pp. 321-391. Academic Press, San Diego (1999)

61. Pastor-Villegas, J., Rodríguez, J.M.M., Pastor-Valle, J.F., Rouquerol, J.: Adsorption-desorption of water vapour on chars prepared from commercial wood charcoals, in relation to their chemical composition, surface chemistry and pore structure. J. Anal. Appl. Pyrolysis 88, 124-133 (2010)
62. Chen, S., Yang, M., Ba, Ch, Yu, S., Jiang, Y., Zou, H., Zhang, Y.: Preparation and characterization of slow-release fertilizer encapsulated by biochar-based waterborne copolymers. Sci. Total Environ. 615, 431-437 (2018)

63. Ali, K., Arif, M., Jan, M.T., Khan, M.J., Jones, D.L.: Integrated use of biochar: a tool for improving soil and wheat quality of degraded soil under wheat-maize cropping pattern. Pak. J. Bot. 47(1), 233-240 (2015)

64. Reibe, K., Roß, C.L., Ellmer, F.: Hydro-/biochar application to sandy soils: impact on yield components and nutrients of spring wheat in pots. Arch. Agron. Soil Sci. 61(8), 1055-1060 (2015)

65. Asai, H., Samson, B.K., Stephan, H.M., Songyikhangsuthor, K., Homma, K., Kiyono, Y., Inoue, Y., Shiraiwa, T., Horie, T.: Biochar amendment techniques for upland rice production in Northern Laos: 1. Soil physical properties, leaf SPAD and grain yield. Field Crop. Res 111, 81-84 (2009)

Publisher's Note Springer Nature remains neutral with regard to jurisdictional claims in published maps and institutional affiliations. 